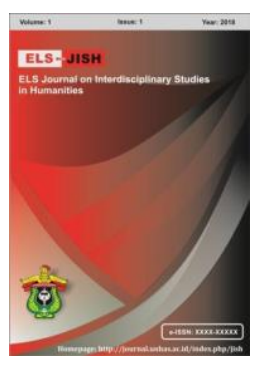

ELS-JISH

ELS Journal on Interdisciplinary Studies on Humanities

Volume 3 Issue 4, 2020

ISSN (print) : 2621-0843

ISSN (online) : 2621-0835

Homepage : http://journal.unhas.ac.id/index.php/jish

\title{
Cultural Dimension of Black Representation of Ammatoa Community: Study of Cultural Semiotics
}

\author{
Tadjuddin Maknun ${ }^{1}$, M. Dalyan Tahir ${ }^{2}$, Ita Suryaningsih ${ }^{3}$ \\ 1tadjuddinm@unhas.ac.id
}

\begin{abstract}
One of the community groups in South Sulawesi Province, to be precise in Benteng Hamlet, Tana Toa Village, Kajang District, Bulukumba Regency is known as the Ammatoa community. This community is unique compared to other community groups in Bulukumba Regency, which always appears in black traditional clothes. Of course, this phenomenon raises academic questions as to why the Ammatoa community always appears in traditional black clothes. In fact, apart from always appearing in black, the Ammatoa community also has a white identity color, especially in "pacaka pute" (knee-length pants). However, this paper only focuses on black representations. This paper aims to examine the hidden dimension behind the black representation of the Ammatoa community in Bulukumba Regency, South Sulawesi. To analyze the cultural dimension in question, the semiotic theory of culture is used. Data were collected by means of participatory observation and interviews. The participatory observation method is carried out by directly observing the attitudes and patterns of daily life actions of the Ammatoa community. The interview method was carried out by interviewing the customary leader and several other community members about the cultural system or cultural value that underlies the appearance of the all-black clothing. Both methods are accompanied by audiovisual recording and note-taking techniques. Data were analyzed qualitatively - interpretatively. The results showed that the representation of black in the traditional clothing of the Ammatoa community has a symbolic meaning: (1) human life eventually becomes 'dark'; (2) the attitude of "sabbarak" (patient), "gattang" (firm), "lambusuk" (honest), and "pisona" (surrender); (3) "tallasak kamasemase ri lino" ('living unpretentiously in the world) and "kalumannyang kalupepeang allo ri boko" (rich in the afterlife), "inne lino pammari-mariangji" (this world is just a stopover), "akherak pammantang karakkang" (afterlife is an eternal place). This concept is embedded in the oral folklore "pasang ri Kajang" 'messages (rules / norms) for the Kajang community'. In addition, there are pairs of signs of opposition (binnery opposotion), namely "pute"' (white) x "lekleng" (black / dark); "ammumba" (rising) $x$ "sakra" (setting); "kamase-mase" (unpretentious) $x$ "kalumannyang" (rich); "singarak" (light) x "sassang" (dark); "lino" ('world) 'x "akherak" (afterlife); "tallasak" (alive) x "mate" (dead).
\end{abstract}

Keywords: Black Clothes, Ammatoa, Tallasak Kamase-Mase.

How to cite: Maknun, T., Tahir, M.D., \& Suryaningsih, I. (2020). Cultural Dimension of Black Representation in Ammatoa Community in Bulukumba District, South Sulawesi: Study Of Cultural Semiotics. ELS Journal on Interdisciplinary Studies in Humanities, 3(4), 651-660. DOI: https://doi.org/10.34050/elsjish.v3i4.12346

\footnotetext{
${ }^{1,2,3}$ Hasanuddin University, Makassar, Indonesia
} 


\section{Introduction}

In different societies, the color black is viewed differently. In ancient Egypt, the colour of black was a sign of life and regeneration, while in western culture it represented death and sorrow. Moreover, the people of Thai, Tibetan, and Indonesian society claim that colour is associated with bad. However, in Javanese culture, black can be interpreted as a symbol of wisdom and equality. Psychologically, people who like black have characteristics or traits such as being mysterious, dignified, classy, conservative, dark, assertive, strong in stance, preferring to formal situations, and accustomed to being in a strong structure.

The Kajang ethnic group (now referred to as the Kajang people) is one of the ethics that resides privately in South Sulawesi, specifically in Bulukumba Regency. The area(region), of which the local community is called it Tana Toa (the Old Land). This region is headed by a local leader named Ammatoa. Ammatoa leads his people as one community by carrying out the customary law (Rahman, et al., 2019). This community is unique compared to other communities because members of the community always appear in black clothes. All black clothes such as clothes, sarongs, knee-length trousers and headgear are worn by men. As for all black clothes such as kebaya and sarongs, worn by women without a head covering. This all-black outfit is a traditional outfit as well as the color of the Ammatoa community's identity.

Apart from black, there is also white as their identity color.This white color is only found on the knee-length pants worn by men. These white knee-length trousers are only worn by certain groups in the social structure of the Ammatoa community such as the customary leaders and other traditional leaders. The other community members wear black knee-length pants. So, it can be said that the white color on the knee-length pants is also the color of the Ammatoa community identity. However, in this paper the color white is not discussed.

Regarding the color of the Ammatoa community identity, of course, raises questions regarding the Ammatoa community's perception of the color black. In other words, what is the hidden dimension or cultural values (Sumarsono in Oktavianus, 2006) behind the all-black traditional clothes of the Ammatoa community.

So, the main problem discussed in this paper is the cultural dimension of black representation in the traditional clothing of the Ammatoa community. This problem is studied using a cultural semiotic perspective or theory.

\section{Review of Related Literature}

Cultral semiotics is an area of study in semiotics that aims to describe culture from a semiotic perspective and as a process of human symbolic action, the development of signs and a way to provide meaning to everything around it. Here, thus, cultures are interpreted as a system of signals or symbolic signs (Lorusso, 2015)

From this definition, there are two terms, namely semiotic and culture. First, it is better to explain the meaning of semiotics. Semiotics is the science that studies signs in human life (Noth, 1990; Hoed, 2018; Johansen \& Larsen, 
2002). This means that everything that is present in our life is seen as a sign, that is, something that we must give meaning. In other words, what is in our lives is seen as a "form" which has a certain "meaning", is not personal, but social, that is, it is based on social conventions (Rahman, 2017). In connection with this view, Chandler (2017) defines, "Semiotics involves the study not only of what we refer as" signs ", everyday speech, but of anything which expresses" stand for "anything else".

In general, signs can be classified into two major groups, namely (1) signs as dyadic relations and (2) signs as triadic relations. Saussure defines the sign in the concept relation (signified concept) and form (signifier) (Hidayat, 2004; Santosa, 2003). The relationship between marker and marker is considered arbitrary and only occurs by convention. Therefore, Saussurean thinks that research should be directed at the "real" aspects that embody the concept (Hidayat, 2004).

The structural concept of the signifier-signified de Saussure was further developed by Barthes (1957) to become a theory about metilingual and connotations. The term signifier becomes an expression (Expression) and the signified becomes the content (Content). Furthermore, between $E$ (expression) and $C$ (content) there must be a certain $R$ (relation) so that a sign (sign $=S n$ ) is formed. The concept of relation $(\mathrm{R})$ makes the theory of sign more likely to develop because $\mathrm{R}$ is defined by the user of the sign. Expressions can develop and form new signs so that there may be more than one marker with the same C. This development is called a meta-language symptom and forms synonymy. Each sign always gets an initial meaning which is known as "primary system" (generally called denotation), while its development is called "secondary system". The secondary system that leads to $\mathrm{E}$ is called "metlanguage", while the secondary system that points to $C$ is called "connotation", that is, the development of $C$ (content) an $\mathrm{E}$. This connotation concept is, of course, based not only on cognition, but also by understanding. pragmatics, namely the user of the sign and the understanding situation. Apart from the users of the signs, the emotive aspect is one of the factors that form connotations. Furthermore, if the connotation has dominated society, it will become a myth (Hoed, 2008; Kurniawan, 2001). With this system Barthes was inspired to develop it into the field of culture. that is, the sign user and his understanding situation. Apart from the users of the signs, the emotive aspect is one of the factors that form connotations. Furthermore, if the connotation has dominated society, it will become a myth (Hoed, 2008; Kurniawan, 2001). With this system Barthes was inspired to develop it into the field of culture. that is, the sign user and his understanding situation. Apart from the users of the signs, the emotive aspect is one of the factors that form connotations. Furthermore, if the connotation has dominated society, it will become a myth (Hoed, 2008, Kurniawan, 2001). With this system Barthes was inspired to develop it into the field of culture.

Furthermore, signs can be seen from the perspective of tripartite relations. A sign must consist of three elements, namely (1) representation; (2) reference or object; and (3) interpretants. Representation is a representation of the first - a concrete one (can be captured with the human senses), which then goes through a process, representing "something" that exists in human 
cognition (Hoed, 2008; Zimar, 2008; Rusmana, 2014).In other words, representation has the potential to refer to reality and lead to interpretation. This kind of relationship allows the sign as something "growing", depending on the context. This perspective requires researchers to always pay attention to form, meaning, and interpretation in one study (Hidayat, 2004). Reference or object is something that is in human cognition. The process of relation from representation to object is called semiosis, namely icons, indexes and symbols. This semiosis process must continue into a process called interpretant (the process of interpretation). The relationship of three aspects, namely representaments, objects, and interpreters in a semiotic process, this semiotic theory is called a trichotomy or triadic which forms a sign system.

The two perspectives described above have differences and similarities. Peirce's perspective (triadic relations) has a background in pragmatic thinking, while de Saussure's perspective (diadic relations) has a background in structural thinking. The similarity can be seen in the relationship "Representament" where objects (icons, indexes, and symbols) can be aligned with the denotative concept as the first relation; interpretants can be aligned with the concept of connotation. The concept of this connotation developed into a myth in society.

Furthermore, in semiotic development, both structuralists and pragmatics direct their attention to cultural studies. This happens because it is humans who are in their socio-cultural environment that give meaning to the sign. So, semiotics sees culture as a sign system which members of the community give meaning in accordance with applicable conventions (Hoed, 2008).

If culture is considered a sign system (sign network), that system functions as a means of structuring people's lives. Citizens' understanding of the sign system that applies in society allows them to behave in accordance with what is expected of them by fellow citizens because there is an appropriate interpretation of the signs used (Masinambow, 2002). Therefore, if the norms in behavior are violated, it will cause a feeling of discomfort in his mind (Wiranata, 2002).

Culture is the whole system of ideas, actions and human work in the context of community life which is made the property of humans by learning (Wiranata, 2002; Kottak, 2013; Rahman, 2018). In line with this opinion, Koentjaraningrat (2002) argues that culture it has at least three forms, namely (1) the form of culture as a complex of ideas, ideas, values, norms, regulations, etc. (2) the form of culture as a complex of patterned behavioral activities of humans in society; and (3) cultural forms as objects of human work (artifacts) .These three cultural forms cannot be separated and influence one another.

So, culture as a sign system includes sign process, codes, and media (channel). The sign process includes the sign, interpreter, and message. Code consists of a set of signifiers, a set of signifieds, and a set of rules. Both the sign process and codes require a medium as a means to distribute them (Lorusso, 2015). 


\section{Research Methodologhy}

This research was conducted in Benteng Hamlet, Tanatoa Village, Kajang District, Bulukumba Regency, South Sulawesi Province. Tana Toa Village is inhabited by two community groups, namely the Kajang Luar and Kajang Dalam community groups. The Kajang Luar community lives and resides in another village in the Kajang District area, while the Kajang Dalam community (Ammatoa community) resides in Benteng Hamlet. Furthermore, Bulukumba Regency is located in the southern part of South Sulawesi peninsula, approximately $160 \mathrm{~km}$ from Makassar City, the capital of South Sulawesi Province. The Benteng Hamlet itself is approximately $40 \mathrm{~km}$ from the city of Bulukumba. The trip to the hamlet can be reached by using a vehicle (motorbike or car), but the vehicle only reaches the outer Kajang border, not allowed to enter the Kajang Dalam area.

The data collection method used in this research is participatory observation. This method is carried out by taking an active role or being directly involved in the socio-cultural activities of the Ammatoa community. In addition to conducting participatory observations, he also conducted interviews with the customary leaders and other customary leaders to obtain data related to the social and cultural dimensions of the Ammatoa community's perceptions of the colors white and black. To help ensure that the results of the interview were not scattered and easily forgotten, audiovisual instruments were recorded. While interviewing the chairperson and customary stakeholders, a note-taking technique was also carried out on the provided data card. The data that has been obtained from the field are then analyzed qualitatively-interpretatively.

\section{Result}

Due to Dusun Benteng or the customary area of the community Ammatoais a closed area from outside influences, whoever wants to enter this area is not allowed to bring any equipment characterized by modern technology (camera or cellphone) (Sahib, et al., 2019). In other words, it is prohibited to take pictures or photos in the customary territory of the Ammatoa community (Kajang Dalam). To obtain data in the form of a daily appearance of the Ammatoa community in traditional black clothes (black clothes, black sarongs, black or white knee-length pants, and headgear), the research team implemented a strategy by inviting several traditional leaders to take pictures in the Kajang Luar and Kajang Dalam border areas. Thus, data is obtained in the form of photos as listed below. 

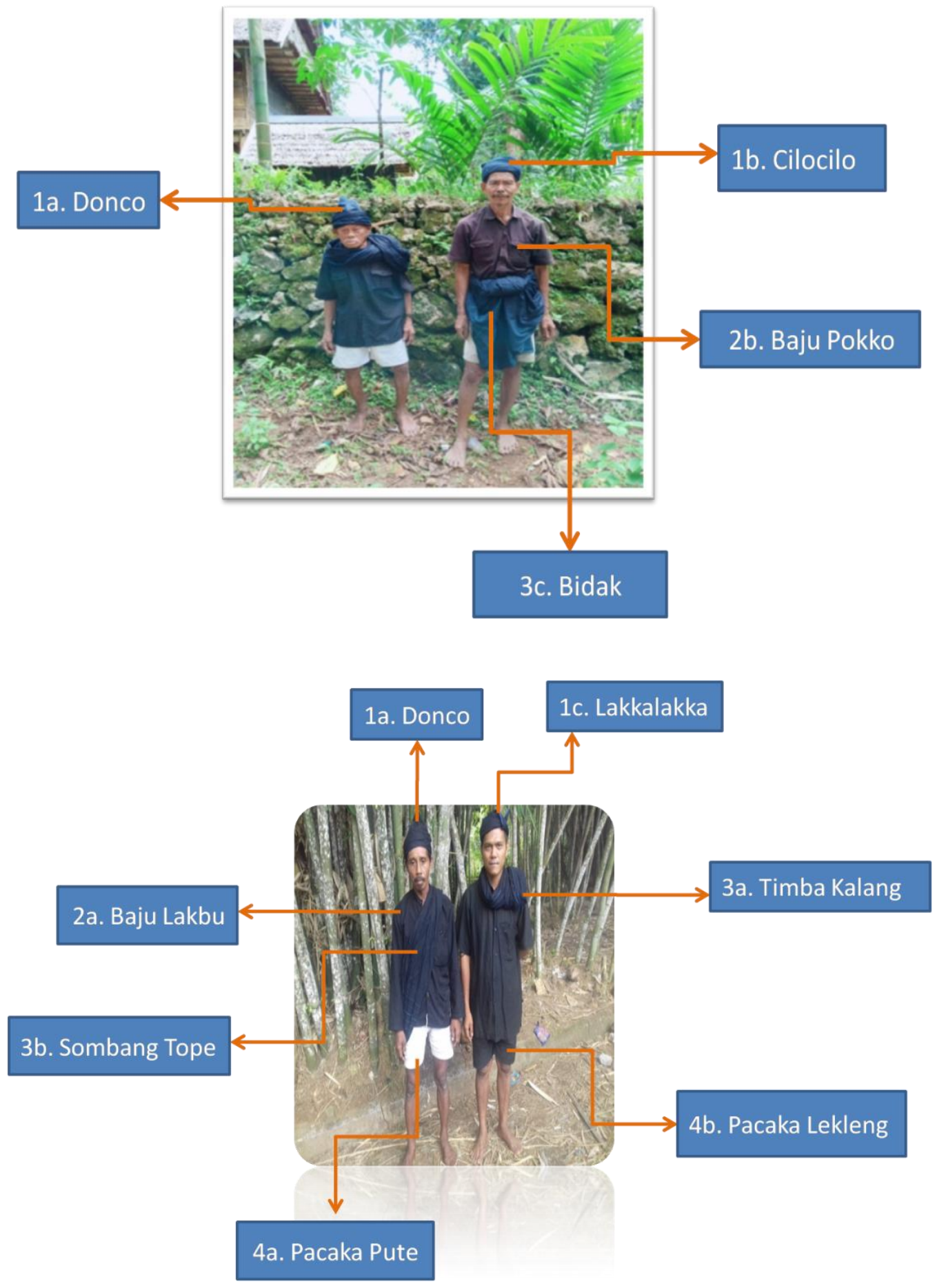


\section{Pokko Lekleng}

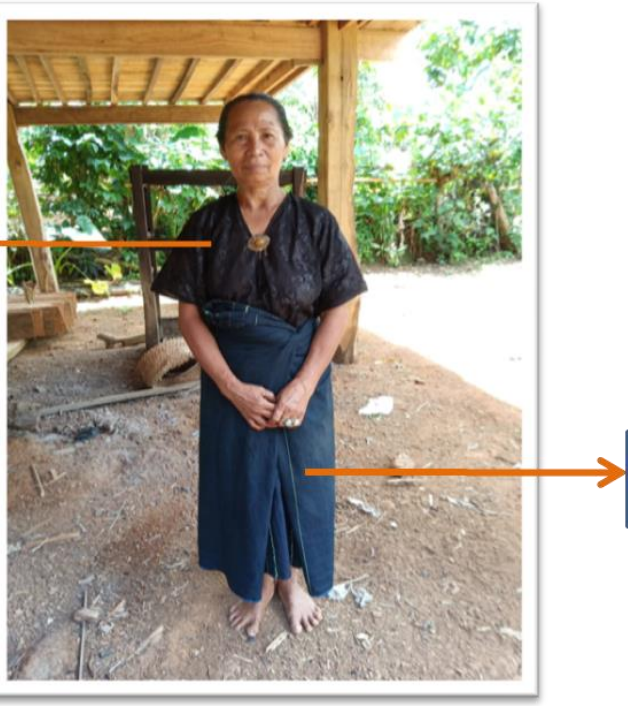

\section{Tope Lekleng}

Image / photo captions:

1. In general, the head covering is called a 'destar' pasapu, but based on the model or shape there are those called:

1a. donco 'headgear with a triangular front side model and a bit tall'

1b. Cilocilo 'headgear with a triangular front side but lower than Donco'

1c. lakkalakka 'headgear with the front side folded inward'

2. In general, the clothes that are worn are called 'clothes', but based on the model or shape there are those called:

2a. lakbu's shirt 'long sleeve shirt';

2b. pokko shirt 'short sleeve shirt';

3. In general, the sarong that is used is called lipak (outer kajang) or tope (inner kajang) 'sarong', but based on the model or how to use it, there is something called:

3a. timba kalang 'wearing the sarong by wrapping it around the neck and placing the other part on the left shoulder;

3b. sembang tope 'wearing a sarong by wrapping it from the left shoulder to the right side of the waist;

3c. the wearing of the sarong by wrapping it around the body and the upper edge being rolled up;

4. In general, knee-length pants that are worn are called saloara (Outer Kajang) or pacaka (Inner Kajang), but based on the color there are those called:

4a. pacaka pute'white pants'

4b. pacaka lekleng 'black pants'

5. Pokko lekleng 'short sleeve shirts for girls'

6. Tope lekleng 'black sarong for girls' 


\section{Discussion}

The black representation in the Ammatoa community has several meanings, namely (1) dark when the sun sets in the western horizon; (2) eternal, firm, and honest; (3) simplicity / similarity; and (4) death.

The representation of black has the meaning of 'dark' because iconically when the sun sets on the western horizon (in Makassar language it is called sakra), the sunlight becomes lost so that the atmosphere becomes dark. The connotative representation of black symbolizes that human life will eventually become dark (sassang in Makassar language) which is in opposition to light (singarak in Makassar language). In other words, the black representation symbolizes the end point of the journey of human life in the world, while the white representation symbolizes the starting point of the journey of human life in the world.

Black representation is interpreted as 'firm, eternal / consistent, honest' because iconically, even though it is treated in any way, it still displays its original color, it will not change like any other color. Thus, this black color becomes the color of the Ammatoa community's identity, which symbolizes the 'firm' gattang character, in the sense of being consistent in attitudes and behavior based on cultural values stored inasang ri Kajang 'messages, rules, norms that apply in Kajang'.

In addition, black symbolizes the character of lambusuk 'honest', in the sense that what is imprinted in the heart, that is also what is manifested in action. The representation of black means 'simple' because iconically the color black does not indicate a glamorous nature (luxurious, festive, and sparkling). Furthermore, this color connotative for the Ammatoa community is a symbol of the tallasak kamase-mase 'simple life'. That is, the Ammatoa community lives life as it is; do not have excessive desires in daily life, both for food and for other needs; make use of the surrounding environment as needed; suppressing the need if it is deemed to damage the existence of the natural environment These attitudes and behaviors are manifestations of the ri kajang pair which reads "Jagai lino lollong bonena, kammaya tompa langika, the form of tau siagang boronga", which means "take care of the world and its contents, as well as the sky, humans and forests".

Furthermore, the Ammatoa community thinks that the life of the world is only temporary (kunne, Konjo dialect) or "inne linoa pammari-mariangji", meaning 'this world is only a haven', while life after death (konjo mange, Konjo dialect) or "aherak pammantangngang karakkang ", Meaning 'the hereafter is a place or life that is eternal or eternal' is the main goal, namely" kalumannyang kalupepeang ri allo ri bokona Turie Arakna means, "a self-sufficient life in the next day belongs to God ".

In addition, the principle of "tallasak kamase-mase" encourages the owner to "ammentengko nukamase-mase", which means "to stand you are simple"; "Accidongko nukamase-mase", means "to sit you are simple"; "Addakkako nukamase-mase" means "walk you simply"; "Akmea nukamase-mase", which means "speak you humbly". 
By implementing the principle of tallasak kamase-mase in their daily life, they do not want to accept goods from outside, especially the products of modern technology. Thus, this community includes people who are still living primitive and left behind compared to other communities in Bulukumba Regency.

\section{Conclusion}

The black representation among the Ammatoa community symbolizes: (a) attitudes and behavior of simple life (tallasak kamase-mase) in the world and living well in the hereafter (kalumannyang kalupepeang ri allo ri boko); (b) mental attitude of being patient (sabbarak), firm (gattang), honest (lambusuk), and submissive (pisona); and (c) that man will end his life (sakra). Black is the color of identity for the Ammatoa community so that their appearance is different from other community groups in Bulukumba Regency. Signs such as ammumba 'rising' $\mathrm{x}$ sakra 'setting'; tallasak kamase-mase 'simple life' $\mathrm{x}$ kalumannyang kalupepeang 'living well'; singarak 'light' x sassing 'dark'; pute 'white x lekleng' black '; lino 'world' x akherak 'afterlife'; and tallasak 'live x mate 'mati'are elements that are in opposition, but still have a logical relationship with each other so as to form a unity of meaning (coherence) that applies in the culture of the Ammatoa community.

\section{References}

Chandler, D. (2017). Semiotic The Basic - Third Edition. In Routledge, Taylor \& Francis Group.

Hidayat, R. (2004). "Semiotika dan Bidang IImu". Dalam T. Christomy dan Untung Yuwono (Ed.) Semiotika Budaya. Depok: Pusat Penelitian Kemasyarakatan dan Budaya, Direktorat Riset dan Pengabdian Masyarakat UI.

Hoed, H. (2008). Semiotik dan Dinamika Budaya. Jakarta: Fakultas IImu Pengetahuan Budaya, UI.

Johansen, J. D., \& Larsen, S. E. (2002). Sign In Use: An Introduction to Semiotics. London: Routledge Taylor and Fracis Group.

Koentjaraningrat. (2002). Kebudayaan Mentalitas dan Pembangunan. Jakarta: Gramedia Pustaka Utama.

Kotta, Pillip Conrad. 2013. Anthropology: Appreciating Human Diversity. Fifteenth Edition. New York: McGraw-Hill.

Kurniawan. 2001.Semiologi Roland Barthes. Magelang: Indonesiatera.

Lorusso, A. M. (2015). Cultural Semiotics. In Cultural Semiotics. https://doi.org/10.1057/9781137546999

Maras, S. (2002). A Semiotics of the Proxy. Jurnal Social Semiotics, 12(1). Cartax Publishing, Taylor \& Francis Group.

Masinambow, E.K.M dan Hidayat. (2002). Semiotik (Kumpulan Makalah Seminar). Depok: Pusat Penelitian Kemasyarakatan dan Budaya, Lemabaga Penelitian Uniersitas hasanuddin. 
Noth, W. (1990). Handkbook of Semiotics. Bloomington: Indiana University Press.

Rahman, F. (2017). Analyzing Literary Works through Linguistic Structuralism Approach (Semiotics, Stylistics, Pragmatics). FIB Press - Faculty of Cultural Sciences Hasanuddin Univiersity.

Rahman, F. (2018). The Constraints of Foreign Learners in Reading English Literary Works: A Case Study at Hasanuddin University. Journal of Arts and Humanities, 7(2), 01. https://doi.org/10.18533/journal.v7i2.1327

Rahman, F., \& Letlora, P. S. (2018). Cultural Preservation: Rediscovering the Endangered Oral Tradition of Maluku (A Case Study on Kapata of Central Maluku). Advances in Language and Literary Studies, 9(2), 91.

Rahman, F., Akhmar, A. M., \& Amir, M. (2019, May). The Practice of Local Wisdom of Kajang People to Save Forests and Biodiversity: A CulturalBased Analysis. In IOP Conference Series: Earth and Environmental Science (Vol. 270, No. 1, p. 012038). IOP Publishing.

Santosa, R. (2003). Semiotika Sosial; Pandangan terhadap Bahasa. Surabaya: Pustaka Eureke \& JPP Press.

Sahib, H., Rahman, F., Duli, A., \& Asba, A. R. (2019). Customary Forest Conservation through Informal Knowledge System of Ammatowa Community. In IOP Conference Series: Earth and Environmental Science (Vol. 270, No. 1, p. 012042). IOP Publishing.

Wiranata, I Gede. (2002). Antropologi Budaya. Bandung: Citra Aditya Bakti. 